\title{
História
}

\section{Entrevista com Denise de Souza Fleith}

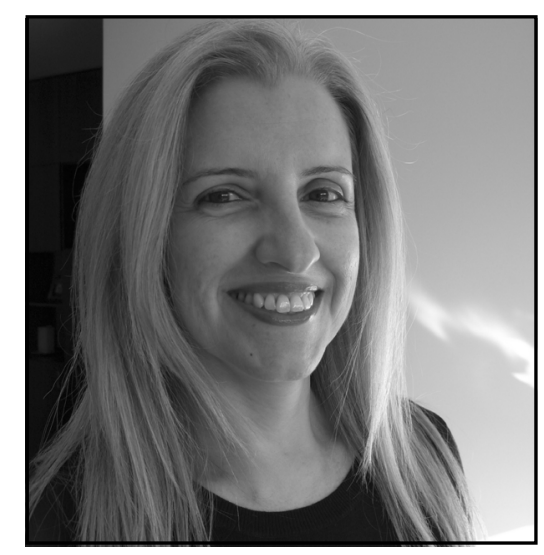

\section{Entrevistadora: Lucicleide Maria de Cantalice}

Denise de Souza Fleith é graduada em Psicologia pela Universidade de Brasília (1985), realizou o mestrado na mesma instituição, na área de Psicologia da Aprendizagem e do Desenvolvimento, defendendo sua dissertação no ano de 1990. Concluiu o doutorado em Psicologia Educacional pela University Of Connecticut (1999) e posdoutorado pela University of Warwick (2005) . Atualmente é professora adjunta da Universidade de Brasília, no Departamento de Psicologia Escolar e do Desenvolvimento.Realizou ao longo de sua carreira estudos na área de Psicologia, com ênfase em Psicologia Educacional, atuando principalmente nos temas relacionados a criatividade, treinamento de criatividade, bilingüismo, autoconceito e superdotação.

Lucicleide: Você poderia contar um pouco sobre sua formação profissional e o que a motivou a optar pela Psicologia Escolar e Educacional?

Denise: Em agosto de 1985 me formei em Psicologia (opções Psicólogo e Licenciatura) pela Universidade de Brasília. A seguir, realizei o mestrado, na mesma universidade, na área de Psicologia da Aprendizagem e do Desenvolvimento. A dissertação de mestrado foi defendida no início de 1990. Em 1991, assumi o cargo de professora assistente no Departamento de Psicologia Escolar e do Desenvolvimento na Universidade de Brasília, após ser aprovada em concurso público. No período de 1995 a 1999, realizei doutorado em Psicologia
Educacional na University of Connecticut, nos Estados Unidos, sob orientação do prof. Joseph Renzulli, grande líder na área de educação de alunos superdotados e talentosos. Recentemente, concluí estágio pós-doutoral na National Academy for Gifted and Talented Youth, na University of Warwick, Inglaterra. Trata-se de um centro de pesquisa e atendimento ao superdotado respeitado mundialmente. Posso afirmar que o meu interesse pela área de Psicologia Escolar e Educacional despertou ainda durante o curso de graduação em Psicologia, quando tive chance de cursar várias disciplinas e de realizar estágios em Licenciatura e em Psicologia Escolar. Ademais, as oportunidades que tive de conhecer o trabalho desenvolvido em grandes centros 
de pesquisa contribuíram para fortalecer minha opção pela área de Psicologia Escolar e Educacional.

Lucicleide: $O$ que foi relevante para você se tornar pesquisadora e escolher a criatividade e superdotação como temas de investigação?

Denise: Durante a graduação, no início dos anos de 1980, cursei a disciplina Psicologia da Criatividade, com a profa. Eunice Soriano de Alencar. Era uma área nova, que chamou a minha atenção. Tive ainda a grande oportunidade de trabalhar em projetos de pesquisa sobre criatividade no contexto escolar com a referida professora e ser por ela orientada no mestrado. Além disso, fiz estágio na área de superdotação sob a supervisão da profa. Solange Wechsler, que havia recentemente retornado de seu doutorado nos Estados Unidos (realizado sob a orientação do prof. Torrance, renomado pesquisador da área de criatividade). Estas experiências foram marcantes e definiram o caminho que trilhei na área de Psicologia Escolar.

Lucicleide: Como vê os estudos sobre criatividade e superdotação no Brasil?

Denise: Podemos observar um aumento gradual de pesquisas sobre criatividade e superdotação no Brasil. Esta área tem despertado o interesse de vários alunos de pós-graduação e de profissionais que atuam na área escolar. Ademais, estes estudos têm contribuído para desmistificar idéias errôneas disseminadas em nossa sociedade acerca do processo criativo e do indivíduo superdotado, bem como sugerido estratégias eficientes de estimulação da criatividade e do potencial promissor no contexto escolar e familiar. Alguns esforços têm sido envidados por alguns pesquisadores da área com vistas à construção e/ou validação de instrumentos de avaliação da criatividade.

Lucicleide: Qual a importância da iniciação científica e da pós-graduação na formação do psicólogo e, em especial, para prepará-lo para trabalhar na área educacional?
Denise: É fundamental que o psicólogo que atua na área educacional tenha uma formação sólida, tanto do ponto de vista teórico quanto metodológico, utilize um referencial consolidado em sua prática profissional, adote uma postura de trabalho preventivo e desenvolva habilidades de análise crítica. $\mathrm{O}$ contato do aluno com a atividade de pesquisa na graduação e pós-graduação, a participação em congressos científicos, envolvendo apresentação de trabalhos, contribui para esta formação, amplia sua visão acerca do papel do psicólogo escolar e educacional e favorece uma reflexão sobre a atuação deste profissional.

Lucicleide: $O$ que tem sido mais estimulante e desafiador em sua atuação profissional?

Denise: Trabalhar com alunos de pós-graduação que precisam trabalhar enquanto realizam seu mestrado ou doutorado. O tempo de dedicação às dissertações e teses muitas vezes fica comprometido dado os inúmeros compromissos profissionais que assumem. Por outro lado, entendo ser difícil para o aluno que precisa sustentar a família se dedicar integralmente a uma pós-graduação contando apenas com uma bolsa de estudo. Outro desafio é atender as inúmeras demandas, inclusive administrativas, que acompanham o trabalho do professor e pesquisador dentro dos prazos estabelecidos.

Lucicleide: Qual é hoje, a seu ver, concretamente, a situação da Psicologia Escolar?

Denise: Minha percepção é a de que os profissionais que atuam nesta área estão pouco a pouco se conscientizando das múltiplas tarefas que podem desenvolver, do papel inovador que podem exercer na escola, da necessidade de se trabalhar interdisciplinarmente, indo além das atribuições tradicionalmente delegadas ao psicólogo escolar. Acredito ainda que este profissional gradualmente vem obtendo mais visibilidade no contexto escolar. Certamente, a criação de associações científicas, como a ABRAPEE, a condução e divulgação de estudos na área têm contribuído para esta mudança de cenário. Naturalmente, há ainda um longo caminho a ser 
percorrido, mas com certeza, a situação hoje é mais favorável do que a de décadas atrás.

Lucicleide: Quais seriam as questões teóricopráticas presentes na relação entre Psicologia e Educação no momento atual brasileiro?

Denise: Existem diversas questões que merecerem atenção. Destacarei uma delas - o impacto da educação à distância (ou on-line) em vários aspectos do desenvolvimento cognitivo, social e emocional do ser humano como, por exemplo, a relação professor(tutor)-aluno, a avaliação de desempenho e, naturalmente, o processo criativo.
Lucicleide: Qual a contribuição que a Psicologia Escolar pode dar à sociedade brasileira?

Denise: São inúmeras as contribuições da Psicologia Escolar para a sociedade brasileira. Destaco especialmente a importância da área no desenvolvimento de indivíduos criativos, críticos, autônomos, socialmente competentes e responsáveis, na formação de professores que saibam reconhecer, valorizar e estimular o potencial humano e no trabalho de orientação à família. 